\title{
Hemocytic neoplasia in the Chilean oyster (Tiostrea chilensis) cultured in the south of Chile. New record
}

\author{
Patricia Rojas Z., Mariel Campalans B. and Marcelo González A. \\ Escuela de Ciencias del Mar, Universidad Católica de Valparaíso \\ Casilla P.O. Box 1020 Valparaíso 1, Chile \\ E-mail: mcampala@ucv.cl
}

Recibido 28 abril 1998; versión corregida 13 enero 1999; aceptado 8 marzo 1999.

\begin{abstract}
A neoplasic condition in the Chilean oyster Tiostrea chilensis is described. The condition is characterized by the infiltration and replacement of enlarged, atypical, and mitotically-active cells, apparently of hemocytic origin. The etiology of Tiostrea chilensis neoplasia remains uncertain.
\end{abstract}

Keywords: Neoplasia, Tiostrea chilensis, oyster, bivalve mollusc, pathology, diseases.

\section{Neoplasia hemocitica en la ostra chilena (Tiostrea chilensis) cultivada en el sur de Chile. Nuevo registro}

RESUMEN: Se describe una condición neoplásica de la ostra chilena Tiostrea chilensis. Esta condición se caracteriza por la infiltración y reemplazo de las células del tejido conectivo por células atípicas de gran tamaño mitóticamente activas, aparentemente de origen hemocítico. La etiología de la neoplasia en Tiostrea chilensis permanece incierta.

Palabras claves: Neoplasia, Tiostrea chilensis, ostra, molusco bivalvo, patología, enfermedades.

\section{INTRODUCTION}

The disease known as haemocytic condition has been found in a wide variety of marine bivalve molluscs (Peters, 1988). In oysters, this kind of neoplasia has been described for at least seven farmed species from around the world (Elston, 1994).

In Chile, an apparently similar condition in Tiostrea chilensis (Philippi, 1845) (=Ostrea chilensis) was reported by Mix and Breese (1980). This paper ratifies the suspected neoplasic condition previosly reported and now found in several oyster farms in the south of Chile.

\section{MATERIAL AND METHODS}

The oyster were obtained from six farmer centers located near Calbuco $\left(41^{\circ} 45^{\prime} \mathrm{S}, 74^{\circ} 45^{\prime} \mathrm{W}\right)$, Ancud (41 $\left.55^{\prime} \mathrm{S}, 74^{\circ} 50^{\prime} \mathrm{W}\right)$ and Castro ( $\left.42^{\circ} 25^{\prime} \mathrm{S}, 74^{\circ} 55^{\prime} \mathrm{W}\right)$ south of Chile (Fig.1), between June 1996 and January 1997. Tissue samples of mantle, digestive gland and gills were processed for histological analysis, fixed with a formaldehyde solution buffered with phosphate; dehydrated through ethanol series, cleared in xylene and embedded in paraffin. Thin sections of $5 \mu \mathrm{m}$, stained with hematoxylin-eosin were scanned microscopically for detecting abnormalities and/or parasites.

\section{RESULTS AND DISCUSSION}

The neoplasic condition was found in $4.5 \%$ of the total examined specimens, most of the diseases animals were from Ancud and Calbuco. No positive cases were found in the oyster from Castro (Table 1).

The neoplasic oysters did not show external signs of the disease even though the histopathological analyses of most of the examined specimens presented a widely distributed proliferative tissue in the digestive gland and the mantle's connective tissue. The neoplasic tissue is characterized by atypical cells of abnormal size (9 to $12 \mu \mathrm{m}$ in diameter), as compared with normal hemocytes (measuring from 6 to $10 \mu \mathrm{m}$ in diameter); with a basophilic nucleus in the range of 8 to $10 \mathrm{um}$ in diameter, which largely overrides the normal hemocyte nucleus of 3 to 4 


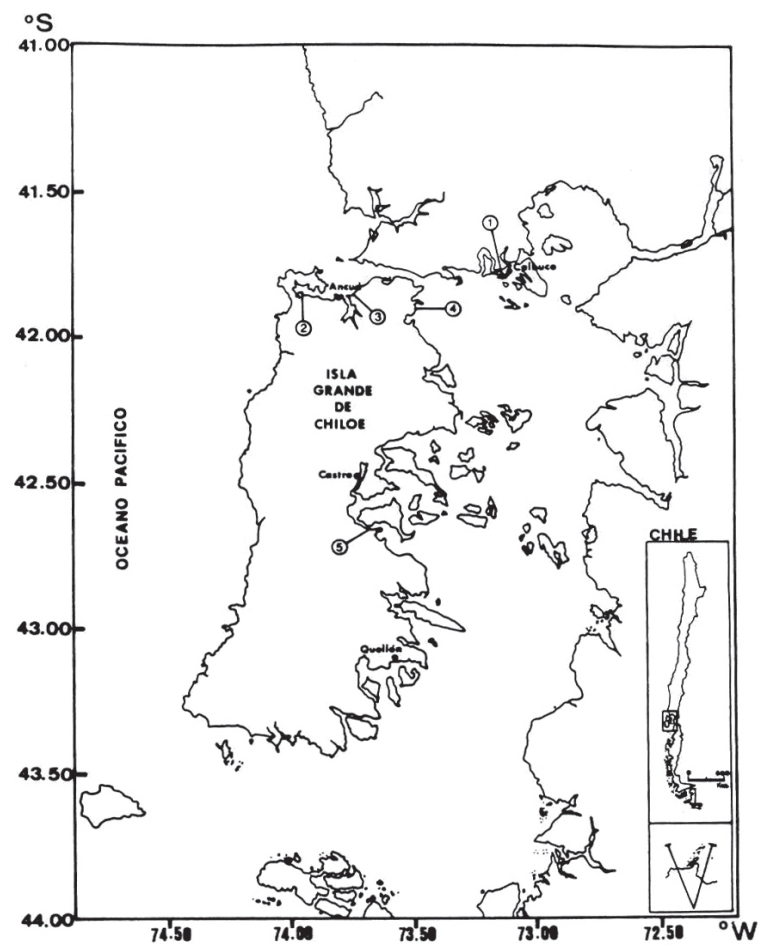

Figure 1. Location of study area and sampling sites.

Figura 1. Localización del área de estudio y sitios muestreados.

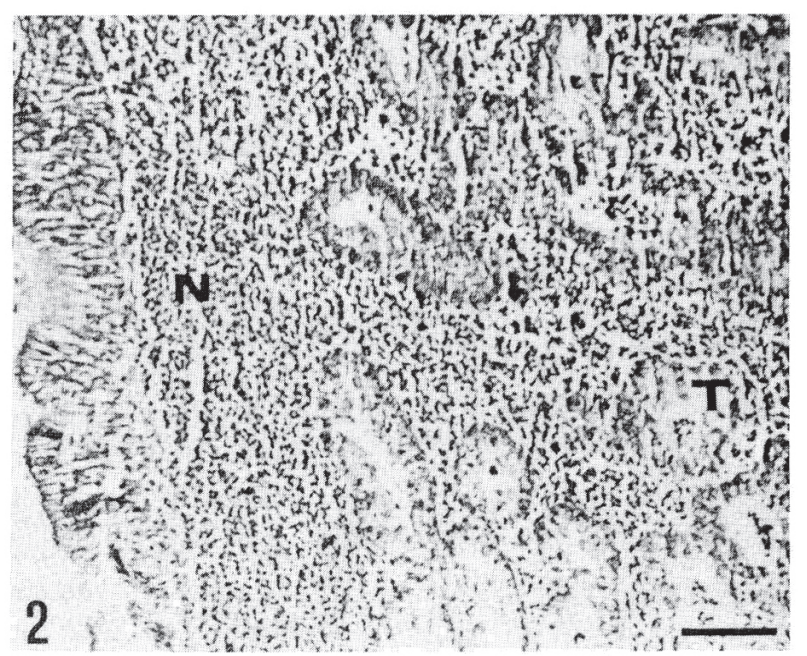

Figure 2.Tiostrea chilensis. Histological section of digestive gland showing infiltration of connective tissue by neoplastic cells $(\mathrm{N})$. Digestive tubules $(\mathrm{T})$. Scale bar $=200 \mu \mathrm{m}$.

Figura 2. Tiostrea chilensis. Sección histológica de la glándula digestiva mostrando una infiltración del tejido conjuntivo por células neoplásicas (N). Túbulos digestivos (T). Barra= $200 \mu \mathrm{m}$. 


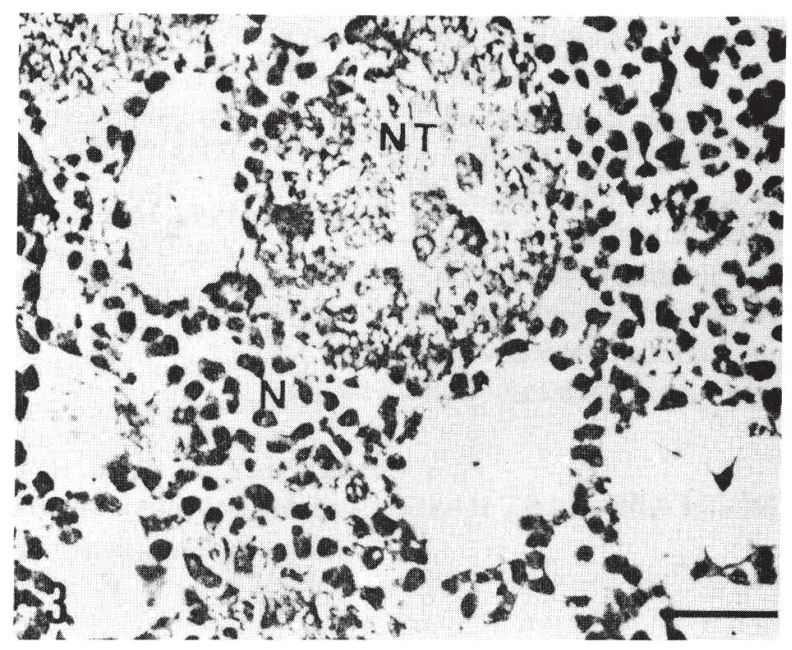

Figure 3. Tiostrea chilensis. Histological section of digestive gland showing severe infiltration of connective tissue by neoplastic cells $(\mathrm{N})$ with associated necrotic digestive tubules $(\mathrm{NT})$. Scale bar= $\mathbf{5 0} \mu \mathrm{m}$.

Figura 3. Tiostrea chilensis. Sección histológica de la glándula digestiva mostrando una severa infiltración del tejido conjuntivo por células neoplásicas $(\mathrm{N})$ asociados a túbulos digestivos necróticos. Barra =50 $\mu \mathrm{m}$.

Table 1. Number and percentage of Tiostrea chilensis with neoplasia in relation to the collection sites. Tabla 1. Número y porcentaje de Tiostrea chilensis con neoplasia en relación con los sitios de recolección.

\begin{tabular}{|lcccc|}
\hline $\begin{array}{l}\text { Sampling } \\
\text { Locality }\end{array}$ & Area & $\begin{array}{c}\text { Number of } \\
\text { oysters }\end{array}$ & $\begin{array}{c}\text { Neoplasic } \\
\text { cases }\end{array}$ & $\%$. \\
\hline Quinhua Channel & Calbuco & 28 & 1 & 4.7 \\
Quetalmahue Bay & Ancud & 25 & 1 & 4.0 \\
Quempillén River & Ancud & 27 & 2 & 7.4 \\
Hueihue Bay & Ancud & 59 & 4 & 6.7 \\
Teupa & Castro & 28 & 0 & 0.0 \\
\hline
\end{tabular}

$\mu \mathrm{m}$. These are mitotically active cells with scarce cytoplasm. The condition is accompanied by the destruction of the digestive tubules.

Mix and Breese (1980) reported neoplasia cases in Ostrea chilensis from Chiloé Island, but failed to establish, whether the oysters were from natural or cultured populations, an important factor in order to discern the possible genetic or crowding effect that could be involved in the neoplasic condition of farmed oysters. Further investigations should be conducted on the natural oyster beds.

Currently the origin of the disease remains uncertain although some scientists associate the disease with the presence of a retrovirus, while others suspect a relationship with chemicals derived from oil pollution (Cheng, 1993). Although the waters in the zone of study are considered within the most clean environments of the world, research results on chlorinated hydrocarbon pollution in sediments (Bonert, 1996), indicated accumulation points of DDT and or its metabolites (such as DDD and DDE). The area is not considered as of being of an important agroindustrial development, nevertheless its organochloride compound levels are comparable to those of largely industrialized areas. Therefore, it is not at all possible to discard the carcinogenic compounds as possible conditioning factors for this pathology. 
Another releasing factor could be associated to genetics. Frierman and Andrews (1976), in due course of an intensive culture program of Crassostrea virginica, discovered groups of highly sensitive individuals to the occurrence of neoplasia, mainly in cultured oysters, while those from natural beds origin showed low numbers of neoplasic cases. Again, it is not as well possible to neglect the possibility of oncogenes implications in the development of neoplasic diseases in invertebrates.

\section{ACKNOWLEDGMENTS}

This study is part of the Project FIP 95-32, financed by the Fisheries Research Fund of the Chilean Undersecretary of Fisheries.

\section{REFERENCES}

Cheng, T. 1993. Noninfections diseases of marine molluscs. In: J.A. Couch and J. W. Fournie (Eds), Pathobiology of Marine and Estuarine Organisms. CRC Press, Boca Raton, pp. 289-318.
Bonert, C. 1996. Hidrocarburos clorados en sedimentos. En Comité Oceanográfico Nacional (Ed.) Resultados Crucero CIMAR-FIORDO 1. CONA, Valparaíso, pp. 58-61.

Elston, R. 1994. Hematopoietic neoplasm of bivalve molluscs. In: J.C.Thoesen (Editor), Suggested Procedures for the Detection and Identification of Certain Finfish and Shellfish Pathogens. 4th Edition,version1, Fish Health Section, American Fisheries Society.

Frierman, E. M. and J. D. Andrews. 1976. Ocurrence of hematopoietic neoplasms in virginia oysters (Crassostrea virginica). J. Nat. Cancer Inst., 56 (2): 319-324.

Mix, M. C. and W. P. Breese. 1980. A cellular proliferative disorder in oysters (Ostrea chilensis) from Chiloe, Chile, South America. J. Invertebr. Pathol., 36: 123-124.

Peters, E. C. 1988. Recent investigations on the disseminated sarcomas of marine bivalve molluscs. In: W. S. Fischer (Ed.) Diseases Processes in Marine Bivalve Molluscs. American Fisheries Society, Washington, Special Publication, No 18 , pp.74-92. 